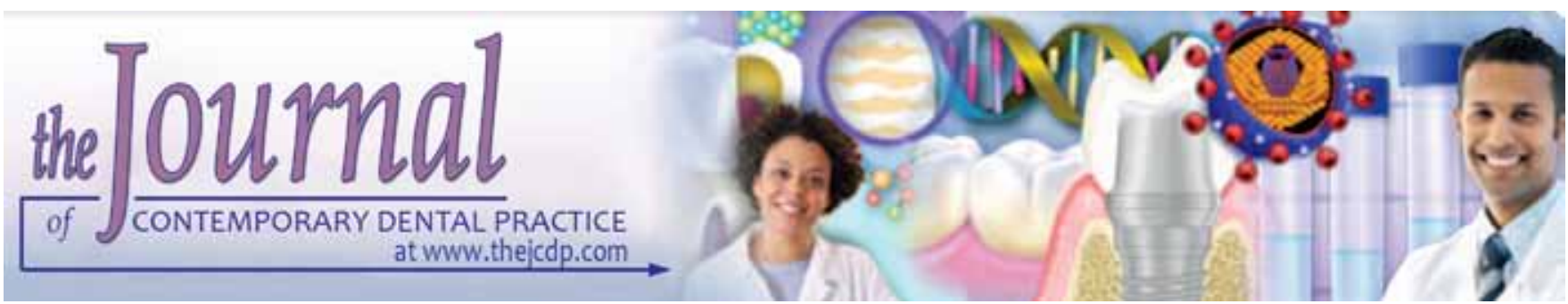

\title{
Power Hydrogen Evaluation of Apexification Materials: EndoCal 10, Mineral Trioxide Aggregate and Calasept Plus
}

${ }^{1}$ Ersan Çiçek, ${ }^{2}$ Emre Bodrumlu

\section{ABSTRACT}

Aim: The present study was to evaluate $\mathrm{pH}$ values of apexification materials.

Materials and methods: The materials were placed in $1 \mathrm{~cm}$ long and $4 \mathrm{~mm}$ diameter tubes. After sample immersion, glass flasks were hermetically sealed with rubber caps to attenuate any effects of external environmental factors and maintained at $37^{\circ} \mathrm{C}$. The power hydrogen of the pastes was measured 1 hour, 3 hours, 8 hours, 24 hours, 72 hours and 7 days after preparation. $\mathrm{pH}$ was calibrated with solutions of known $\mathrm{pH}$ (7.0). Mann-Whitney test were used to determine significant differences.

Results: The mean $\mathrm{pH}$ of all medications was $<12.0$ throughout the experiment. At 24 hours, EndoCal 10 had the highest $\mathrm{pH}$ of all the materials $(p<0.05)$.

Conclusion: According to the results obtained, it may be concluded that calcium oxide (EndoCal 10) presented the higest $\mathrm{pH}$ compared with mineral trioxide aggregate (MTA) and Calasept Plus $\left[\mathrm{Ca}(\mathrm{OH})_{2}\right]$.

Clinical significance: Apexification is an important treatment in immature teeth. For this reason, used materials in apexification should have some properties, such as high $\mathrm{pH}$ and stimulating to be hard tissue. Therefore, the material should be chosen carefully in apexification of immature teeth.

Keywords: Apexification, Immature teeth, $\mathrm{pH}$.

How to cite this article: Çiçek E, Bodrumlu E. Power Hydrogen Evaluation of Apexification Materials: EndoCal 10, Mineral Trioxide Aggregate and Calasept Plus. J Contemp Dent Pract 2015;16(6):463-467.

\footnotetext{
1,2Department of Endodontics, Faculty of Dentistry, Bülent Ecevit University, Zonguldak, Turkey
}

Corresponding Author: Ersan Çiçek, Department of Endodontics, Faculty of Dentistry, Bülent Ecevit University Zonguldak, Turkey, Phone: +903722613413, e-mail: ersancicek@beun.edu.tr

\section{Source of support: Nil}

Conflict of interest: None

\section{INTRODUCTION}

Apexification is a procedure progressing a teeth with immature apex through the formation of osteocementum or other bone like tissue. ${ }^{1-3}$ Many materials, such as calcium hydroxide $\left[\mathrm{Ca}(\mathrm{OH})_{2}\right]$, zinc oxide, calcium phosphate and mineral trioxide aggregate (MTA), have been used to stimulate hard tissue formations during apexification procedure.

Calcium hydroxide has been commonly used for apexification procedures based on its antibacterial, antiresorptive, and tissue-dissolving properties. ${ }^{4-6}$ The high $\mathrm{pH}$ of $\mathrm{Ca}(\mathrm{OH})_{2}$ destructively affects on cell membranes and protein structure of bacteria. ${ }^{7}$ As is well-known, periapical tissues tolerates and subsequently resorbes $\mathrm{Ca}(\mathrm{OH})_{2} \cdot{ }^{8}$ However, $\mathrm{Ca}(\mathrm{OH})_{2}$ chemically alters lipopolysaccharide which affects its various biological properties. ${ }^{9-13}$ High $\mathrm{pH}$, which is bactericidal in $\mathrm{Ca}(\mathrm{OH})_{2}$ is determined by the liberation of hydroxyl ions, which requires an ideal time for effective destruction of microorganisms, and also inhibits osteoclastic activity. ${ }^{14}$ The time required for apical barrier formation in apexification using $\mathrm{Ca}(\mathrm{OH})_{2}$ may be considerable, often as long as 20 months; and other conditions, such as age and presence of symptoms or periradicular radiolucencies may affect the time needed to form an apical barrier.

Mineral trioxide aggregate (MTA) is also used in the apexification treatment because of its favorable sealing ability and biocompatibility. ${ }^{15}$ Mineral trioxide aggregate allows for an immediate apical barrier to be formed and, thus, immediate obturation of the root canal system. Mineral trioxide aggregate may, therefore, solve some of the problems currently experienced in apexification using 
$\mathrm{Ca}(\mathrm{OH})_{2}$. It produces the equivalent amount of apical hard tissue with no more inflammation than $\mathrm{Ca}(\mathrm{OH})_{2}$. Mineral trioxide aggregate has shown potential outcome in carrying out apexification of immature permanent teeth. $^{15}$

A calcium oxide $(\mathrm{CaO})$ product, with the trade name EndoCal 10, a new material used for apexification, is composed of calcium oxide, zinc oxide, ethylene glycol, and purified water. Calcium oxide formerly known as Biocalex 6.9 in the past was redeveloped by manufacturers and renamed EndoCal 10. EndoCal 10 has good physicochemical properties, presents biocompatibility, prolanged release of calcium hydroxide, and stimulates and isolates vital cells of the endodentium and chemical lysis of necrosed cells. ${ }^{16,17}$

However, at present, limited data is available concerning its properties except the manufacturer introduction. Additionally, there is no information about the $\mathrm{pH}$ ability of EndoCal 10 in comparison to other apexification materials.

The purpose of the present study was to assess the $\mathrm{pH}$ values of the EndoCal 10 agent, and compare it with two apexification materials; Calasept Plus $\left[\mathrm{Ca}(\mathrm{OH})_{2}\right]$ and MTA commonly used in apexification.

\section{MATERIALS AND METHODS}

\section{Sample Preparation}

All the tested apexification materials [EndoCal 10 (Albuca Inc, Pointeclaire, Canada), MTA (Dentsply, Tulsa, OK), and Calasept Plus (Nordiska Dental, Sweden)] were mixed according to the manufacturers' instructions and then placed in $1 \mathrm{~cm}$ long glass tubes (Difco Lab, Detroit, Michigan, USA) with open ends that were $4 \mathrm{~mm}$ in diameter containing $10 \mathrm{ml}$ deionized water. Empty PVC tubes (Deutsch and Neumann, Berlin, Germany) comprised the control group $(n=5) 10$ samples were used for each experiment group. After sample immersion, glass flasks were hermetically sealed with rubber caps to attenuate any effects of external environmental factors and maintained at $37^{\circ} \mathrm{C}$ during all experimental periods; $1,3,8,24,72$ hours, and 7 days.

\section{pH Measurement}

The $\mathrm{pH}$ of the pastes were measured at 1, 3, 8, 24, 72 hours and 7 days after preparation using a $\mathrm{pH}$ meter (Procyon, digital pH meter model AS 720, electrode A 11489, Procy Instrumental Científica, São Paulo, SP, Brazil). The pH was calibrated with solutions of known pH (7.0) before and after measurements at each period. Between each measurement, the $\mathrm{pH}$ meter electrode was washed with ultrapure water (Millipore, Milli-Q Plus) and blotdried. Each measurement was carried out triplicate, and the mean value was recorded.

\section{STATISTICAL ANALYSIS}

The data was analyzed statistically by the Kruskall- Wallis non-parametric test using SPSS. The Mann-Whitney test was used to determine significant differences in susceptibility to intracanal medication among experiment species. Significance level was set at $\mathrm{p}<0.05$.

\section{RESULTS}

The mean $\mathrm{pH}$ values measured for the apexification materials at different time periods are shown in Table 1. The controls showed no noticeable change over the experimental period.

The mean $\mathrm{pH}$ of all medications was $<12.0$ throughout the experiment. At 24 hours, EndoCal 10 had the highest $\mathrm{pH}$ of all the materials $(\mathrm{p}<0.001)$.

At the end of first hour, the mean $\mathrm{pH}$ value of MTA was observed as higher than the others and it was statistically different than the other materials $(p<0.05)$. There was no difference among EndoCal 10, $\mathrm{Ca}(\mathrm{OH})_{2}$, and the Control groups ( $\mathrm{p}>0.05)$.

At the end of the third hour, EndoCal 10 showed a stastical difference $(p<0.001)$, but there was no difference between $\mathrm{MTA}$ and $\mathrm{Ca}(\mathrm{OH})_{2}(\mathrm{p}>0.05)$. This difference was continued from this time until the $72 \mathrm{nd}$ hour. Finally, at the end of the 72nd hour, there was no difference between EndoCal 10 and $\mathrm{Ca}(\mathrm{OH})_{2}(\mathrm{p}>0.05)$. However, these materials were different than MTA

Table 1: The mean $\mathrm{pH}$ values of the materials depending on the time

\begin{tabular}{lllll}
\hline Time period & MTA & EndoCal 10 & Ca $(\mathrm{OH})_{2}$ & Control \\
\hline 1 hour & $7.503 \pm 0.03^{\mathrm{a}}$ & $7.208 \pm 0.05^{\mathrm{b}}$ & $7.27 \pm 0.12^{\mathrm{b}}$ & $7.184 \pm 0.04^{\mathrm{b}}$ \\
3 hours & $8.084 \pm 0.13^{\mathrm{A}}$ & $8.406 \pm 0.18^{\mathrm{B}}$ & $8.071 \pm 0.09^{\mathrm{A}}$ & $7.226 \pm 0.03^{\mathrm{C}}$ \\
8 hours & $8.39 \pm 0.18^{\mathrm{d}}$ & $9.045 \pm 0.16^{\mathrm{f}}$ & $8.766 \pm 0.05^{\mathrm{g}}$ & $7.268 \pm 0.03 \mathrm{~h}$ \\
24 hours & $9.036 \pm 0.19^{\mathrm{D}}$ & $11.782 \pm 0.08^{\mathrm{F}}$ & $10.112 \pm 0.09^{\mathrm{G}}$ & $7.306 \pm 0.03^{\mathrm{H}}$ \\
72 hours & $8.925 \pm 0.13^{\mathrm{K}}$ & $11.046 \pm 0.08^{\mathrm{m}}$ & $10.619 \pm 0.29^{\mathrm{m}}$ & $7.41 \pm 0.02^{\mathrm{n}}$ \\
7 days & $8.287 \pm 0.28^{\mathrm{K}}$ & $10.831 \pm 0.24^{\mathrm{L}}$ & $9.742 \pm 0.31^{\mathrm{M}}$ & $7.392 \pm 0.01^{\mathrm{N}}$ \\
\hline
\end{tabular}

There were significant differences among the different characters statistically 
statistically $(\mathrm{p}<0.05)$. At the end of the experiment period (7th day), there was a significant difference among the groups $(\mathrm{p}<0.001)$.

\section{DISCUSSION}

Common clinical signs, such as exudation, hemorrhage, perforation, root resorption, trauma, or incomplete root formation, may indicate the need for intracanal dressing. ${ }^{18}$ In these situations, it is beneficial to clean the canals and to fill them with a medication.

There are several apexification materials available in the dental market. Increased $\mathrm{pH}$ has been reported to have a beneficial effect. The $\mathrm{pH}$ from root canal sealers are the most important chemical characteristics for the promotion of mineralization. ${ }^{19,20}$ Calcium hydroxide is widely used in apexification. However, apexification using MTA provides an alternative treatment modality in immature pulpless teeth. Apexification with MTA and also calcium oxide agents require significantly less time than $\mathrm{Ca}(\mathrm{OH})_{2}$. Calcium oxide is a self-regulating system, a material that is both an active disinfectant and an obturator, as required by the surrounding conditions. EndoCal 10 and MTA include $\mathrm{CaO}$ in its composition. During its setting, hydration reactions take place, resulting in production of $\mathrm{Ca}(\mathrm{OH})_{2}$. When the set material is placed in a solution, it dissociates into $\mathrm{OH}^{-}$and $\mathrm{Ca}^{+2}$ ions, increasing the $\mathrm{pH}$ concentrations in the medium. ${ }^{21}$ The high $\mathrm{pH}$ of the medications may neutralize the acids secreted by osteoclasts and this may help preventing further destruction of mineralized tissue that plays an important role in hard tissue formation. ${ }^{22,23}$

In this respect, few studies have been reported related to the $\mathrm{pH}$ of apexification materials, except for Endocal 10. ${ }^{14,23-25}$

Duarte $^{24}$ reported that MTA immersed in deionized water produced a $\mathrm{pH}$ of 9.07, 24 hours after immersion. This result is very similiar in the present study ( $\mathrm{pH}$ mean for MTA, 9.06, 24 hours after immersion). Mineral trioxide aggregate contains calcium oxide, which is converted to a calcium hydroxide ion upon contact with tissue, fluid or water, thus, raising the $\mathrm{pH}$.

Endocal 10 produced higher $\mathrm{pH}$ from the beginning and continued to do so throughout the experimental period. The $\mathrm{CaO}(67 \%)$ component of Endocal 10 might play an important role in this $\mathrm{pH}$ increasing. Regarding the $\mathrm{pH}$ of the cements evaluated, during the experiment periods, EndoCal 10 exhibited the highest values among all materials studied. This may be due to the presence of $37 \% \mathrm{Ca}(\mathrm{OH})_{2}$ in the composition of EndoCal 10.

The higher $\mathrm{pH}$ may lead this sealer to exhibit more potent antibacterial effect after some time and may support more rapid healing of apical periodontitis. ${ }^{26}$ Probably by eliminating the bacteria with macrophage activation and cell differentiation and inducing biologic sealing of the root apex by the formation of mineralized tissue. $^{25}$

The two important reasons for using $\mathrm{Ca}(\mathrm{OH})_{2}$ as an apexification material are stimulation of the periapical tissues in order to maintain health or promote healing and its antimicrobial effects. ${ }^{23}$

The high $\mathrm{pH}$ of the medications may also neutralize the acids secreted by osteoclasts and this may help in preventing further destruction of mineralized tissue. Concerning $\mathrm{pH}$, if the material releases hydroxyl ion, thus favoring alkalinity, it will also favor repair and promote an antimicrobial action. ${ }^{23}$

Considering all the reasoning on $\mathrm{pH}$ processes and isolated activities at essential enzymatic sites, it is enlightening to associate $\mathrm{Ca}(\mathrm{OH})_{2}$, a substance with a high $\mathrm{pH}$, with harmful biological effects on bacterial cells in order to explain mechanism of action. Most bacteria present in the root canal system grow best at a $\mathrm{pH}$ around 6.5 to 7.5 , and most microorganisms are destroyed at $\mathrm{pH}$ 9.5 , though a few can survive at $\mathrm{pH} 11$ or higher. ${ }^{27}$ The effect of the high $\mathrm{pH} \mathrm{Ca}(\mathrm{OH})_{2}$, influenced by the release of hydroxyl ions, is able to alter the integrity of the cytoplasmic membrane by means of chemical injuries to organic components and transport of nutrients; or by means of the destruction of phospholipids or unsaturated fatty acids of the cytoplasmic membrane, observed in the lipidic peroxidation process, which is a saponification reaction. $^{23}$

Despite the higher success rate of apical formation using $\mathrm{Ca}(\mathrm{OH})_{2}$, long-term follow is essential. However, apexication using MTA provides an alternative treatment modality in immature pulpless teeth. Apexification with MTA and also $\mathrm{CaO}$ agents require significantly less time than $\mathrm{Ca}(\mathrm{OH})_{2} \cdot{ }^{28}$ Mineral trioxide aggregate as an apexification material represents a contemporary version of the primary monoblock. ${ }^{29}$ Apatite-like interfacial deposits form during maturation of MTA, which results in the filling up of gaps induced during the material shrinkage phase and improve the frictional resistance of MTA to the root canal walls. However, $\mathrm{CaO}$ stimulates and isolates vital cells of the endothelium. ${ }^{17}$ Further studies are necessary for a more detailed evaluation of the properties of this material, including its biological effects.

The methodology of this study consisted of filling standardized tubes with the materials to be tested and immersing in distilled water. The $\mathrm{pH}$ was then determined in the resulting solution. ${ }^{30}$ Numerous authors have utilized similar methodology, immersing the plastic 
tubes containing cements in distilled, deionized, or MilliQ water. ${ }^{30-32}$ Distilled water was used due to its purity and neutral $\mathrm{pH} .{ }^{30}$

The materials could be placed in the root canals and it may be evaluated as more clinically relevant substrate. However, there would be some challenges due to potential differences in size of the apical foramina and anatomic variations. ${ }^{32}$ Although the method of placing sealers in plastic tubes and immersing them in glass flasks does not imitate clinical conditions, it attempts to closely do so have resulted in complicated models that are difficult to reproduce and sometimes even to interpret. The tubes were open at both ends, which helped to condense the sealers without any voids and later helped in $\mathrm{pH}$ measurements. This method offers the advantages of simplicity, replication of the results, and time economy, so that in vitro comparisons between different materials can be easily achieved.

\section{CONCLUSIONS AND CLINICAL SIGNIFICANCES}

- According to the results obtained, it may be concluded that calcium oxide (EndoCal 10) presented the highest pH compared with MTA and Calasept Plus during all experiment periods.

- However, additional studies are necessary to evaluate further biological effects.

- Apexification is an important treatment in immature teeth. For this reason, used materials in apexification should have some properties, such as high $\mathrm{pH}$ and stimulating to be hard tissue.

- Therefore, the material should be chosen carefully in apexification of immature teeth.

\section{REFERENCES}

1. Rafter M. Apexification: a review. Dent Traumatol 2005;21:1-8.

2. American Association of Endodontists. Glossary of endodontic terms. 7th edn. Chicago: American association of Endodontists; 2003.

3. Pinkham JR, Casamassimo PS, Saunders WB. Pediatric Dentistry: infancy through adolescence. 3rd ed. Philadelphia; 1999. p. 152-161.

4. Fava LR, Saunders WP. Calcium hydroxide pastes: classification and clinical indications. Int Endod J 1999;32: 257-282.

5. Bystrom A, Claesson R, Sundqvist G. The antibacterial effect of camphorated paramonochlorophenol, camphorated phenol and calcium hydroxide in the treatment of infected root canals. Endod Dent Traumatol 1985;1:170-175.

6. Hasselgren G, Olsson B, Cvek M. Effects of calcium hydroxide and sodium hypochlorite on the dissolution of necrotic porcine muscle tissue. J Endod 1988;14:125-127.

7. Camões IC, Salles MR, Cheviatarese O, Gomes GC. Influence on $\mathrm{pH}$ of vehicle containing glycerin used with calcium hydroxide. Dent Traumatol 2003;19:132-138.
8. Spangberg LSW. Intracanal medication. In: Ingle JI, Bakland LK, editors. Endodontics. 4th ed. Baltimore: Williams and Wilkins; 1994. p. 627-640.

9. Safavi KE, Nichols FC. Effect of calcium hydroxide on bacterial lipopolysaccharide. J Endod 1993;19:76-78.

10. Safavi KE, Nicholls FC. Alteration of biological properties of bacterial lipopolysaccharide by calcium hydroxide. J Endod 1994;20:127-129.

11. Barthel CR, Levin LG, Reisner HM, Trope M. TNF-alpha release in monocytes after exposure to calcium hydroxide treated E. coli LPS. Int Endod J 1997;30:155-159.

12. Nelson-Filho P, Leonardo MR, Silva LA, Assed S. Radiographic evaluation of the effect of endotoxin (LPS) plus calcium hydroxide on apical and periapical tissues of dogs. J Endod 2002;28:694-646.

13. Jiang J, Zuo J, Chen SH, Holliday LS. Calcium hydroxide reduces lipopolysaccharide-stimulated osteoclast formation. Oral Surg Oral Med Oral Pathol Oral Radiol Endod 2003;95:348-354.

14. Solak H, Oztan MD. The $\mathrm{pH}$ changes of four different calcium hydroxide mixtures used for intracanal medication. J Oral Rehabil 2003;30:436-439.

15. D'Arcangelo C, D'Amario M. Use of MTA for orthograde obturation of nonvital teeth with open apices: report of two cases. Oral Surg Oral Med Oral Pathol Oral Radiol Endod 2007;104:98-101.

16. Miñana M, Carnes DL Jr, Walker WA. PH changes at the surface of root dentin after intracanal dressing with calcium oxide and calcium hydroxide. J Endod 2001;27(1):43-45.

17. Goldberg RA, Kuttler S, Dorn SO. The properties of Endocal 10 and its potential impact on the structural integrity of the root. J Endod 2004;30(3):159-162.

18. Martin DM, Crabb HS. Calcium hydroxide in root canal therapy: a review. Brit Dent J 1977;142:277-283.

19. Evcil MS, Colak M. The $\mathrm{pH}$ changes of four different root canal sealers after mixing at various time intervals in vitro. J Contemp Dent Pract 2004;5:71-78.

20. Huang TH, Kao CT. pH measurement of root canal sealers. J Endod 1998;24:236-238.

21. Tagger M. Hydroxyol ions from set endodontic sealers containing calcium hydroxide. J Endod 1988;14:588-591.

22. Stock C. Calcium hydroxide: Root resorption and Perio-Endo lesions. Br Dent J 1985;158:325-334.

23. Estrela C, Sydney G, Bammann L, Felippe Jr O. Mechanism of the action of calcium and hydroxyl ions of calcium hydroxide on tissue and bacteria. Braz Dent J 1995;6:685-690.

24. Duarte MA, Demarchi AC, Yamashita JC, Kuga MC, Fraga Sde C. $\mathrm{pH}$ and calcium ion release of 2 root-end filling materials. Oral Surg Oral Med Oral Pathol Oral Radiol Endod 2003;95:345-357.

25. Parirokh $\mathrm{M}$ and Torabinejad M. Mineral trioxide aggregate: a comprehensive literature review-part I: chemical, physical, and antibacterial properties. J Endod 2010;36:16-27.

26. Tanomaru Filho M, Leonardo MR, Silva LA, Utrilla LS. Effect of different root canal sealers on repair of teeth with chronic periradicular periodontitis. Int End J 1998;31:85-89.

27. Fuss Z, Weiss EI, Shalhav M. Antibacterial activity of calcium hydroxide-containing endodontic sealers on Enterococcus faecalis in vitro. Int End J 1997;30:397-402.

28. Pradhan DP, Chawla HS, Gauba K, Goyal A. Comparative evaluation of endodontic management of teeth with unformed apices with mineral trioxide aggregate and calcium hydroxide. J Dent Child 2006;73:79-85. 
29. Tay FR, Pashley DH. Monoblocks in root canals: a hypothetical or a tangible goal. J Endod 2007;33:391-398.

30. Anthony DR, Gordon TM, Del Rio CE. The effect of three vehicles on the $\mathrm{pH}$ of calcium hydroxide. Oral Surg Oral Med Oral Pathol Oral Radiol Endod 1982;54:560-565.

31. Eldeniz AU, Erdemir A, Kurtoglu F, Esener T. Evaluation of $\mathrm{pH}$ and calcium ion release of Acroseal sealer in comparison with Apexit and Sealapex sealers. Oral Surg Oral Med Oral Pathol Oral Radiol Endod. 2007;103:86-91.

32. Bortoluzzi EA, Broon NJ, Bramante CM, Felippe WT, Tanomaru Filho M, Esberard RM. The influence of calcium chloride on the setting time, solubility, disintegration, and $\mathrm{pH}$ of mineral trioxide aggregate and white Portland cement with a radiopacifier. J Endod 2009;35:550-554. 